\title{
Diversity and distribution of mollusks at three zones of mangrove in Pejarakan, Bali, Indonesia
}

\author{
I KETUT GINANTRA^, I KETUT MUKSIN, IDA BAGUS MADE SUASKARA, MARTIN JONI \\ Biology Program, Faculty of Mathematics and Natural Sciences, Universitas Udayana. Jl. Raya Kampus Unud, Bukit Jimbaran, Kuta Selatan, Badung \\ 80361, Bali, Indonesia. Tel./fax.: +62-361-703137, •email: ketut_ginantra@unud.ac.id
}

Manuscript received: 16 August 2020. Revision accepted: 16 September 2020.

\begin{abstract}
Ginantra IK, Muksin IK, Suaskara IBM, Joni M. 2020. Diversity and distribution of mollusks at three zones of mangrove in Pejarakan, Bali, Indonesia. Biodiversitas 21: 4636-4643. The diversity of mangrove species in mangrove zonations on the coast of Pejarakan plays an important role in the existence of faunal diversity, including those from mollusks. Mollusks are the dominant phylum associated with mangrove habitats, in addition to the species of the Crustacean subphylum. This research aimed to determine the diversity of mollusks and their distribution patterns in three mangrove zones in Pejarakan, Buleleng District, Bali Province, Indonesia. Data collection was conducted by establishing sampling plots across three mangrove zones, i.e. seaward zone, middle zone, and landward zone. There were 23 sampling plots in total with size of each plot was $1 \mathrm{x} 1 \mathrm{~m}$. The species and number of individuals of each species of mollusks were recorded in each quadrat plot. The diversity of mollusks was calculated using the Shannon-Wiener index, evenness index, and dominance index, while the pattern of distribution of mollusks was measured using the Morisita index. The results of the study found 27 species of mollusks, consisting of 19 species from Gastropods group, 7 species from Bivalvia group and 1 species from Polyplacophora (chiton). The seaward zone showed the highest species diversity, while the landward zone had the lowest. Terebralia palustris had the highest abundance with 217 individuals $/ \mathrm{m}^{2}$ and was distributed in the three mangrove zones. Planaxis sulcatus showed the highest abundance $\left(87\right.$ ind. $\left./ \mathrm{m}^{2}\right)$ in the seaward zone, and Telescopium telescopium showed a fairly high abundance and were distributed in the mid zone and the landward zone. In general, mollusks in the mangrove area of Pejarakan was distributed in a group/clustered pattern. The data from this research can serve as a reference in mangrove forest conservation efforts and mangrove forest used for ecotourism.
\end{abstract}

Keywords: Distribution, mangrove forest zoning, mollusks, species diversity

\section{INTRODUCTION}

Mangrove ecosystem is a unique ecotone (transitional area) in tropical regions that connects terrestrial and marine biotas (Giesen et al. 2007). The mangrove ecosystem consists of animal, plant, and microbe organisms that interact with environmental factors in a mangrove habitat. Globally, there are 16.53 million hectares of mangroves in which 3.49 million hectares of them are located in Indonesia (Ministry of Environment and Forestry 2017), suggesting that Indonesia plays important role in mangrove conservation.

One of mangrove ecosystems in Indonesia is located in Pejarakan, Buleleng District, Bali Province. The mangrove forest in Pejarakan covers an area of 260 hectares and is managed by the Nature Conservation Forum Putri Menjangan for conservation and educational tourism/ ecotourism purposes (NCF Putri Menjangan 2016). Pejarakan mangrove forest has a variety of mangrove species and substrate types. There are 13 species of true mangrove plants and several associated mangrove plants found in the mangrove forest in Pejarakan. The species of true mangrove plants include Rhizophora spp., Bruguiera sp., Ceriops spp., Avicennia sp., Sonneratia sp., Lumnitzera sp., Excoecaria sp., Aegiceras sp. and some associated plants, including sea bracelet (Sesuvium portulacastrum), Hibiscus tiliaceus, Calotropis gigantea, and Ipomoea pes- caprae. The growth pattern of mangrove species in the Pejarakan mangrove forest generally follows the natural pattern of mangrove zonation (Ginantra et al. 2018), which can be divided into three zones, including seaward zone, mid zone, and landward zone.

The diversity of mangrove species in mangrove zonations on the coast of Pejarakan plays an important role in the existence of faunal diversity, including those from mollusks. Mollusks are the dominant phylum associated with mangrove habitats, in addition to the species of the Crustacean subphylum. Mollusks in mangrove ecosystems live on the surface of the substrate, in the substrate, and stick to mangrove trees. Most mollusks that live in mangrove ecosystems are the members of the classes of Gastropoda and Bivalvia (Pechenik 2000).

Mangrove mollusks as part of the mangrove forest ecosystem have an important role that directly or indirectly supports the ecological function of mangrove forests. The food chain and nutrient cycle also involve mangrove mollusks as first consumers and as decomposers. Mollusk shells that contain calcium carbonate also play a role in the carbon cycle that occurs in mangrove forests (Hotchkiss and Hall 2010). However, mollusks that live in mangrove ecosystems are greatly influenced by vegetation conditions and environmental change that occurs in the ecosystem. This is because of the nature of the mollusks that live in a sedentary manner, causing the mollusks to accept any 
environmental changes or changes within the mangrove forest (Putra et al. 2018).

The sustainable utilization of mangrove forests requires baseline information on the diversity of mangrove vegetation and fauna species. The focus of this study is to determine the diversity of mollusks and their distribution patterns in three mangrove zones in Pejarakan, Buleleng District, Bali Province, Indonesia. We expected, the results of this research can be used as a reference in mangrove forest conservation and in the utilization of mangrove forests for ecotourism.

\section{MATERIALS DAN METHOD}

\section{Study area and period}

The research was conducted in mangrove ecosystem of coastal areas in Pejarakan, Buleleng District, Bali, Indonesia on an area of 260 hectares (Figure 1). The geographic location at coordinates $8^{0} \quad 07^{\prime} 32.02^{\prime \prime}-8^{0} \quad 07^{\prime}$ 39.11" $\mathrm{S}$ and $114^{0} 34^{\prime} 12.29^{\prime \prime}-114^{0} 34^{\prime} 19.21^{\prime \prime} \mathrm{E}$, altitude between $0.00-11.58 \mathrm{~m}$ above sea level. Temperatures ranging from $24{ }^{0} \mathrm{C}$ to $37{ }^{0} \mathrm{C}$. Average rainfall 20 $\mathrm{mm} / \mathrm{month}$ to $150 \mathrm{~mm} / \mathrm{month}$ (BMKG region III Bali 2019). There are 13 species of true mangrove and 14 mangrove associates (mangrove associates). The dominant species of mangrove are Sonneratia alba, Lumnitzera racemosa, Rhizophora apiculata, Rhizophora mucronata, Ceriops decandra, and Avicennia marina (Ginantra et al. 2018). Part of the Pejarakan mangrove area is the remaining area that has been converted since 1984 . The conversion of the mangrove area at that time included two things, namely cutting down mangroves for fuelwood and replacing them with fish and shrimp ponds. The fish and shrimp pond area has now been turned into a salt pond, so that the existing mangrove area is adjacent to the salt pond area (NCF Putri Menjangan 2016). The fieldwork was conducted in April until September 2019.

\section{Sampling technique}

Fauna analysis was carried out in 23 quadrat plots in which each quadrat had size of $1 \times 1 \mathrm{~m}$. The establishment of quadrat plots was based on mangrove zoning, i.e. SZ1 to SZ8 for the seaward zone (zone near the sea), MZ1 to MZ8 for the middle zone, and LZ1-LZ7 for the landward zone (Figure 1).

The sampling was carried out at low tide. Mollusks were sampled to a depth of $20 \mathrm{~cm}$. In each quadrat plot, the number of individuals of each mollusk species was counted. The mollusk samples were put in bottles and preserved with alcohol $70 \%$, then identification was carried out in the laboratory.

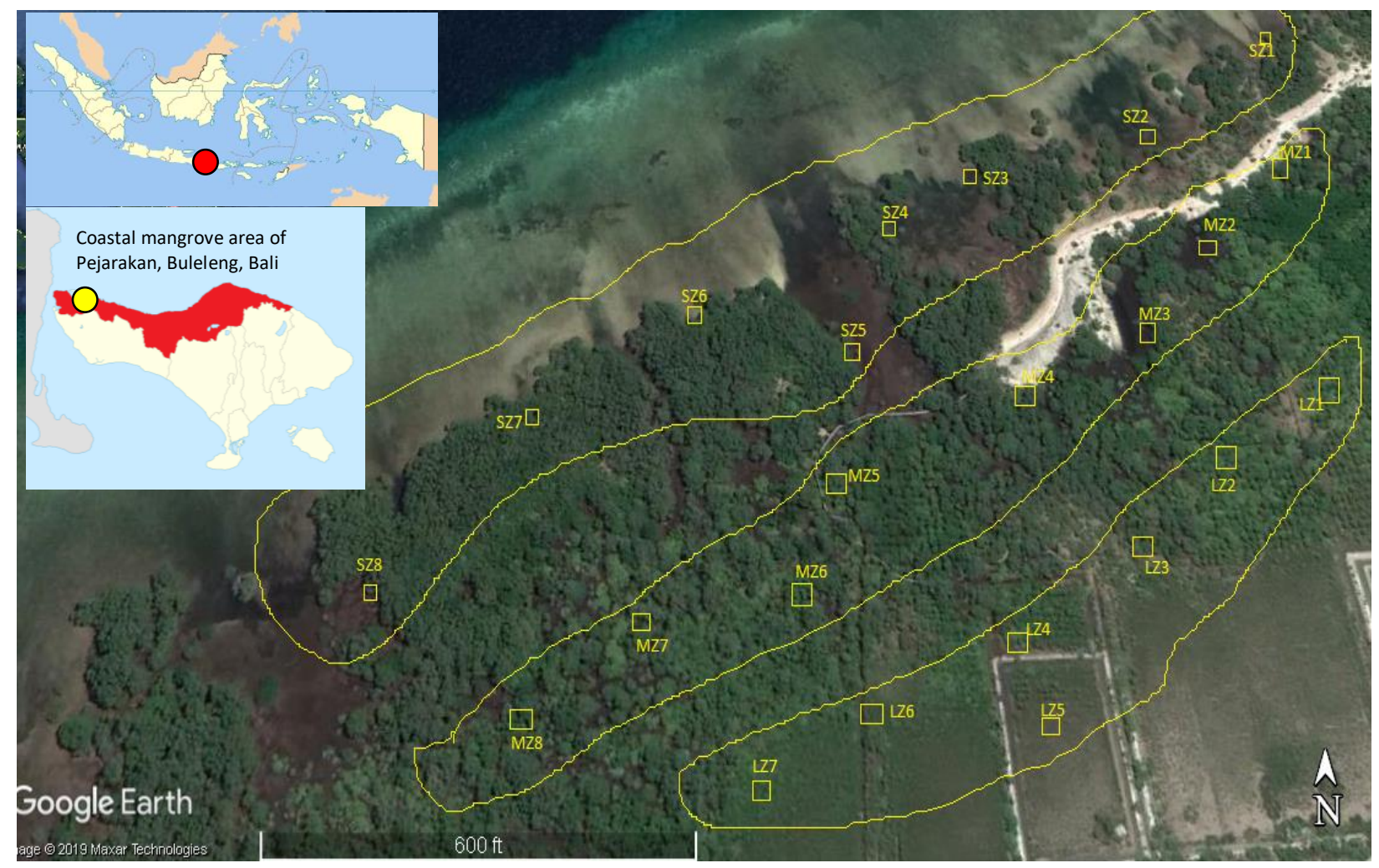

Figure 1. Map of the research sites in Pejarakan $(\mathrm{O})$, Buleleng District, Bali Province, Indonesia. (SZ: seaward zone, MZ: middle zone, LZ: landward zone) 


\section{Identifying the species of mollusks}

All specimens were photographed and identified. Mollusk identification was based on morphological characters (i.e. shape, size, shell texture, and shell color), and identification referred to Tan and Clements (2008) and Nursalwa and Marshall (2014). The identification of mollusk specimens was carried out at the Animal Taxonomy Laboratory of the Biology Study Program, Faculty of Mathematics and Natural Sciences, Udayana University.

\section{Data analysis}

The diversity and evenness of mollusk species were calculated using the Shannon-Wiener diversity index (H'), the evenness index $(\mathrm{E})$, and the dominance index with the formula:

$$
\begin{aligned}
& \mathrm{H}^{\prime}=-\sum[\mathrm{n} i / \mathrm{N} \times \ln (\mathrm{n} i / \mathrm{N})] \\
& \mathrm{E}=\mathrm{H}^{\prime} / \ln \mathrm{S} ; \\
& \mathrm{D}=\sum(\mathrm{n} i / \mathrm{N})^{2}
\end{aligned}
$$

Where, $\mathrm{n} i$ is the importance value of the $i^{\text {th }}$ species and $\mathrm{N}$ is the total importance of all species. The importance value is determined by two parameters, namely relative density and relative frequency, and $S$ is the number of species (Stiling 1996).

The pattern of distribution/dispersion was calculated using the Morisita index, with the formula:

$$
\mathrm{I}_{\mathrm{d}}=\mathrm{n}\left[\sum \mathrm{xi}^{2}-\sum \mathrm{xi} /\left(\sum \mathrm{xi}\right)^{2}-\sum \mathrm{xi}\right]
$$

Where, $\mathrm{I}_{\mathrm{d}}$ : Morista index; $\mathrm{n}$ : Sum of all plots; $\mathrm{xi}$ : Number of individuals of the ith species. The calculated Morisita index was then standardized using Chi-square analysis at the confidence level of $97.5 \%$, degrees of freedom $n-1$ (value $X^{2} .975$, table at $n-1$ is 10.982 , and $\mathrm{X}^{2} .025$, table at $\mathrm{n}-1$ is 36.781$)$.

The uniform index $\left(\mathrm{M}_{\mathrm{u}}\right)$ and the Clumped index $\left(\mathrm{M}_{\mathrm{c}}\right)$ were calculated with the formula:

$$
\begin{aligned}
& M_{u}=\left[X^{2}, 975-n \sum x i\right] /\left[\sum x i-1\right] ; \\
& M c=\left[X^{2} .025-n \sum x i\right] /\left[\sum x i-1\right] ;
\end{aligned}
$$

if $I_{d}$ is greater than $M_{c}$ and greater than 1 , then the Morisita index was standardized using the formula:

$$
\left(I_{p}\right)=0.5+0.5\left[\left(I_{d}-M_{c}\right) /\left(n-M_{c}\right)\right]
$$

The Morisita standard index $\left(\mathrm{I}_{\mathrm{p}}\right)$ is ranging from -1.0 to 1.0 in which the distribution shows a random pattern if $\mathrm{I}_{\mathrm{p}}=$ 0 , clustering if $\mathrm{I}_{\mathrm{p}}>0$, and uniform if $\mathrm{I}_{\mathrm{p}}<0$.

\section{RESULTS AND DISCUSSION}

\section{Diversity of mollusks}

The results of the study found 27 species of mollusks in which most of them were from the Gastropod class (snails) with 19 species, the other was from the Bivalvia class with 7 species and 1 species from the Polyplacophora class (chiton) (Table 1). The most dominant species of mollusks in three mangrove zones was the giant mangrove whelk (Terebralia palustris) with a density of $217 \mathrm{ind} . / \mathrm{m}^{2}$. The tropical periwinkle sea snail (Planaxis sulcatus) was dominant in the seaward zoning with a density of 87 ind. $/ \mathrm{m}^{2}$. The Bivalvia class composition was quite evenly distributed between one another (Table 1). Several species of mollusks were found in two zones while some species were only in one zone. Species of the Bivalvia class were generally found in two zones, namely in the seaward and the middle zone, and only one species was found in the landward zone, namely Ostrea edulis.

Overall, the diversity of mollusks in the mangroves is in the medium category with a Shanon-Wiener diversity index of 2.96, an evenness index of 0.91 , and a dominance index of 0.18 . (Figure 2). Based on the diversity index, species evenness index, and dominance index, it can be said that the mangrove conditions in this area are still quite good. The seaward mangrove zone had the highest diversity of mollusks, namely 23 species of mollusks with a diversity index $(\mathrm{H})$ of 2.78 , an evenness index of 0.89 , and a dominance index of 0.16 . The lowest diversity is shown in landward zone with 6 mollusks species, and a diversity index of 1.34, an evenness index of 0.69 and a dominance index of 0.42 . The high diversity of mollusks in the seaward zone is likely related to the high diversity of vegetation, habitat complexity and variations in the type of substrate. The seaward zone had the most diverse mangrove plant species and substrate types (Table 2), resulting in the high production of mangrove litter, which is the most important intake for mollusks. In the middle zone and the landward zone, the diversity of mangrove vegetation was lower, the root type of mangroves was less varied as well as the substrate type, so that the diversity of mollusks was also low. The low diversity of mollusks in the landward zone is likely also caused by environmental pressures due to human activities, waste from salt ponds in the form of mud, and solid waste entering the mangroves. Waste can interfere with the breeding grounds for mollusks, and garbage can also cover the surface of the substrate/roots of mangroves containing food ingredients so that it can prevent mollusks from eating.

The availability of food derived from the decay of mangrove leaves and associated algae affects the diversity of mangrove fauna. Piranto et al. (2019) also found that the high diversity of mangrove species and substrates in Pramuka Island, Jakarta Bay affected the diversity of mollusks, especially species from the Gastropoda class. In mangrove ecosystem in Lombok Island, Mujiono (2016) stated that the highest species diversity was found in the seaward zone. The geographical factor of mangrove forests of the seaward zone located on the coast allows gastropod species from the sea to enter, either intentionally to find food or because they are carried away by waves.

The abundance, biomass and diversity of mollusks in mangrove communities are most likely influenced by the physical structure of mangrove forests (including the pneumatophores and related epiphytic algae), sediment texture and mangrove detritus. In addition, studies in mangrove stands show differences in benthic biomass and 
diversity associated with mangrove age (Kabir et al. 2014, Baderan et al. 2019, Halim et al. 2019, Sahidin et al. 2019). In general, this study shows that even small-scale modifications to the structure of mangrove ecosystems can have a significant effect on the diversity and abundance of mollusks in these habitats.

Table 1. The diversity and abundance of mollusks species (ind. $/ \mathrm{m}^{2}$ ) in the three mangrove zones of Pejarakan coastal area, Bali, Indonesia

\begin{tabular}{|c|c|c|c|c|c|}
\hline \multirow{2}{*}{ Class } & \multirow{2}{*}{ Species } & \multicolumn{3}{|c|}{ Mangrove zone } & \multirow{2}{*}{$\begin{array}{c}\text { Total } \\
\text { individual }\end{array}$} \\
\hline & & SZ & MZ & $\mathbf{L Z}$ & \\
\hline Gastropoda & Assiminaea sp. & 6 & - & - & 6 \\
\hline Gastropoda & Cerithidea obtusa & 5 & - & 5 & 10 \\
\hline Gastropoda & Cerithideopsilla alata & 7 & - & 10 & 17 \\
\hline Gastropoda & Conus frigidus & 5 & 7 & - & 12 \\
\hline Gastropoda & Conus sponsalis & 5 & - & - & 5 \\
\hline Gastropoda & Cypraea anulus & 7 & - & - & 7 \\
\hline Gastropoda & Cypraea caputserpentis & 4 & - & - & 4 \\
\hline Gastropoda & Cassidula sp. & - & - & 5 & 5 \\
\hline Gastropoda & Melampus sp. & 6 & - & - & 6 \\
\hline Gastropoda & Monodonta sp. & - & 5 & - & 5 \\
\hline Gastropoda & Monodonta canalifera & 7 & 4 & - & 11 \\
\hline Gastropoda & Nerita planospira & 5 & - & - & 5 \\
\hline Gastropoda & Nerita sp. & 19 & - & - & 19 \\
\hline Gastropoda & Nerita costata & 5 & - & - & 5 \\
\hline Gastropoda & Littoraria strigata & - & 14 & - & 14 \\
\hline Gastropoda & Planaxis sulcatus & 87 & - & - & 87 \\
\hline Gastropoda & Semiricinula tissoti & 8 & 6 & - & 14 \\
\hline Gastropoda & Terebralia palustris & 78 & 58 & 81 & 217 \\
\hline Gastropoda & Telescopium telescopium & - & 20 & 13 & 33 \\
\hline Polyplacophora (chiton) & Acanthopleura granulata & 5 & - & - & 5 \\
\hline Bivalvia & Modiolus micropterus & 12 & - & - & 12 \\
\hline Bivalvia & Crassostrea rhizophorae & 5 & - & - & 5 \\
\hline Bivalvia & Ostrea edulis & 7 & - & 11 & 18 \\
\hline Bivalvia & Anadara sp. & 9 & 7 & - & 16 \\
\hline Bivalvia & Anadara granosa & 5 & 7 & - & 12 \\
\hline Bivalvia & Polymesoda bengalensis & 6 & 5 & - & 11 \\
\hline \multirow[t]{3}{*}{ Bivalvia } & Saccostrea sp. & 5 & 5 & - & 10 \\
\hline & Total of individual & 308 & 138 & 125 & 571 \\
\hline & Total of species & 23 & 11 & 6 & - \\
\hline
\end{tabular}

Note: SZ: seaward zone; MZ: middle zone; LZ: landward zone

Table 2. Characteristics of mangroves in the three zones of mangrove in Pejarakan coastal area, Bali, Indonesia

\begin{tabular}{|c|c|c|c|}
\hline Characteristic & Seaward Zone & Mid Zone & Landward Zone \\
\hline Vegetation & $\begin{array}{l}\text { Species of mangroves: Sonneratia } \\
\text { alba, Rhizophora apiculata, } \\
\text { Rhizophora mucronata, Avicennia } \\
\text { marina, Lumnitzera apiculata, } \\
\text { Ceriops decandra, Ceriops tagal, } \\
\text { Aegiceras floridum } \\
\text { The height of mangroves between 7- } \\
15 \mathrm{~m} \\
\text { The prominent types of mangrove } \\
\text { roots are pneumatophore, knee root } \\
\text { and stilt root }\end{array}$ & $\begin{array}{l}\text { - Species of mangrove; Sonneratia } \\
\text { alba, Avicennia officinalis, } \\
\text { Ceriops decandra, Rhizophora } \\
\text { apiculata, Rhizophora } \\
\text { mucronata. } \\
\text { - The height of mangroves } \\
\text { between 6-11 m } \\
\text { - The prominent types of } \\
\text { mangrove roots are stilt root and } \\
\text { pneumatophore }\end{array}$ & $\begin{array}{l}\text { - Species of mangrove; } \\
\text { Lumnitzera racemosa, } \\
\text { Sonneratia alba, Excoecaria } \\
\text { agallocha, plants associated } \\
\text { with mangrove. } \\
\text { - The height of mangroves } \\
\text { between } 2-8 \mathrm{~m} \\
\text { The prominent type of } \\
\text { mangrove roots is } \\
\text { pneumatophore. }\end{array}$ \\
\hline
\end{tabular}

Substrate Sandy, gravel, rock, slightly muddy mud depth up to $10 \mathrm{~cm}$. Water level is high enough when the tide is high or low.
Sufficiently deep muddy (up to $50 \mathrm{~cm}$ Quite densely muddy, little rocky. deep), little rocky. Standing water in Low standing water to dry when the some locations is quite high but water recedes. mostly low during low tide. 


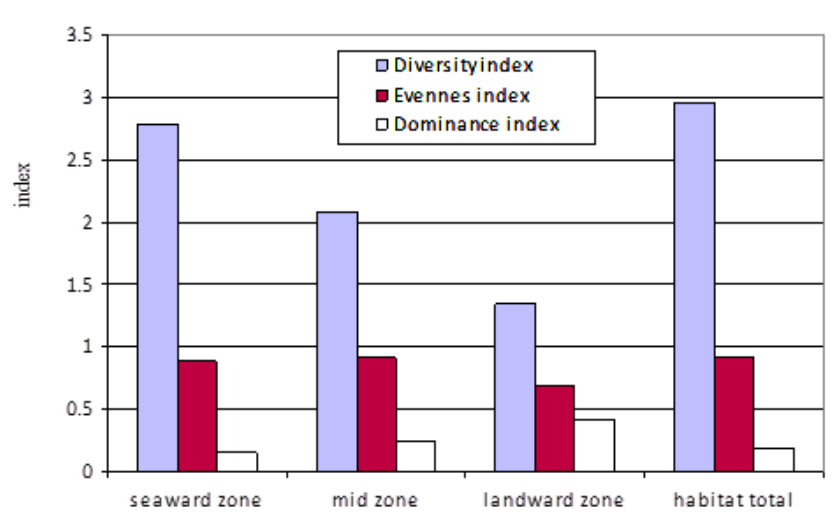

Figure 2. Species diversity of mollusks in the three mangrove zones in Pejarakan coastal area, Bali, Indonesia

\section{Distribution of mollusks in the mangrove zones}

Based on the calculation of the spread index $\left(I_{d}\right)$ and the standardized Morisita index (Ip), it shows that the distribution of mollusks species in the three mangrove zones had the $I_{d}$ ranging from $1.34-8.00$ and $I_{p}$ ranging from 0.52-1.00 (Table 3). The species of mollusks with the highest indexes were $\mathrm{I}_{\mathrm{d}} 8.00$ and $\mathrm{I}_{\mathrm{p}} 1.00$, meaning that these species were distributed in groups only in one plot in each zone. Species that were found only in one plot including Cerithidea obtusa, Conus frigidus, Conus sponsalis, Cypraea caputserpentis, Nerita planospira, and Anadara granosa. Meanwhile, the distribution index $\left(\mathrm{I}_{\mathrm{d}}\right)$ of mollusks which is close to 1 or $I_{p}$ is close to 0 indicates that these species are distributed in groups in several samples in each zone (i.e. located in more than $50 \%$ of the sample plots). Species of mollusks that were distributed in clustered patterns in several plots were Terebralia palustris and Modiolus micropterus.

Modiolus micropterus was distributed in several plots in the seaward zone, and slightly in the landward zone. Habitat characteristics in the seaward zone support the life of this species of seashell, i.e. the sandy mud substrate type. Widiana et al. (2016) stated that the habitat of this Bivalvia species is generally in mud or sandy mud in the littoral area, and the life of the species immerses as "filter feeders" that accumulate filtered material in their gills. In the process, bacteria and other microorganisms in the surroundings can accumulate and reach dangerous amounts for consumption. Food is one of the factors that cause seashell to be uniform. It is suspected that the availability of food in the habitat is a factor that affects the distribution at each location which is uniform.

Table 3. The distribution pattern of mollusks species in three zones of mangrove in Pejarakan coastal area, Bali, Indonesia

\begin{tabular}{|c|c|c|c|c|c|c|c|c|c|}
\hline \multirow{2}{*}{ Species } & \multicolumn{3}{|c|}{ Seaward zone } & \multicolumn{3}{|c|}{ Mid zone } & \multicolumn{3}{|c|}{ Landward zone } \\
\hline & $\mathbf{I}_{\mathbf{d}}$ & $\mathbf{I}_{\mathbf{p}}$ & Patterns & $\mathbf{I}_{\mathrm{d}}$ & $\mathbf{I}_{\mathrm{p}}$ & Patterns & $\mathbf{I}_{\mathbf{d}}$ & $\mathbf{I}_{\mathbf{p}}$ & Patterns \\
\hline Assiminaea $\mathrm{sp}$. & 3.56 & 0.63 & groups & - & - & - & - & - & - \\
\hline Cerithidea obtusa & 8.00 & 1.00 & groups & - & - & - & 7.00 & 1.00 & groups \\
\hline Cerithideopsilla alata & 8.00 & 1.00 & groups & - & - & - & 3.23 & 0.64 & groups \\
\hline Conus frigidus & 8.00 & 1.00 & groups & 8.00 & 1.00 & groups & - & - & - \\
\hline Conus sponsalis & 8.00 & 1.00 & groups & - & - & - & - & - & - \\
\hline Cypraea anulus & 2.29 & 0.55 & groups & - & - & - & - & - & - \\
\hline Cypraea caputserpentis & 8.00 & 1.00 & groups & - & - & - & - & - & - \\
\hline Cassidula sp. & - & - & - & - & - & - & 7.00 & 1.00 & groups \\
\hline Melampus sp. & 3.56 & 0.63 & groups & - & - & - & - & - & - \\
\hline Monodonta sp. & - & - & - & 8.00 & 1.00 & groups & - & - & - \\
\hline Monodonta canalifera & 3.56 & 0.63 & groups & 8.00 & 1.00 & groups & - & - & - \\
\hline Nerita planospira & 8.00 & 1.00 & groups & - & - & - & - & - & - \\
\hline Nerita $\mathrm{sp}$ & 8.00 & 1.00 & groups & - & - & - & - & - & - \\
\hline Nerita costata & 8.00 & 1.00 & groups & - & - & - & - & - & - \\
\hline Littoraria strigata & - & - & - & 2.35 & 0.56 & groups & - & - & - \\
\hline Planaxis sulcatus & 4.29 & 0.73 & groups & - & - & - & - & - & - \\
\hline Semiricinula tissoti & 2.33 & 0.56 & groups & 8.00 & 1.00 & groups & - & - & - \\
\hline Terebralia palustris & 1.34 & 0.52 & groups & 1.37 & 0.53 & groups & 1.35 & 0.52 & groups \\
\hline Telescopium telescopium & - & - & - & 8.00 & 1.00 & groups & 3.41 & 0.66 & groups \\
\hline Acanthopleura granulata & 3.43 & 0.61 & groups & - & - & - & - & - & - \\
\hline Modiolus micropterus & 1.75 & 0.53 & groups & - & - & - & 7.00 & 1.00 & groups \\
\hline Crassostrea rhizophorae & 8.00 & 1.00 & groups & - & - & - & - & - & - \\
\hline Ostrea edulis & 3.73 & 0.65 & groups & - & - & - & 7.00 & 1.00 & groups \\
\hline Anadara sp. & 1.79 & 0.53 & groups & 8.00 & 1.00 & groups & - & - & - \\
\hline Anadara granosa & 8.00 & 1.00 & groups & 8.00 & 1.00 & groups & - & - & - \\
\hline Polymesoda bengalensis & 3.56 & 0.63 & groups & 3.56 & 0.63 & groups & - & - & - \\
\hline Saccostrea sp. & 8.00 & 1.00 & groups & 8.00 & 1.00 & groups & - & - & - \\
\hline
\end{tabular}



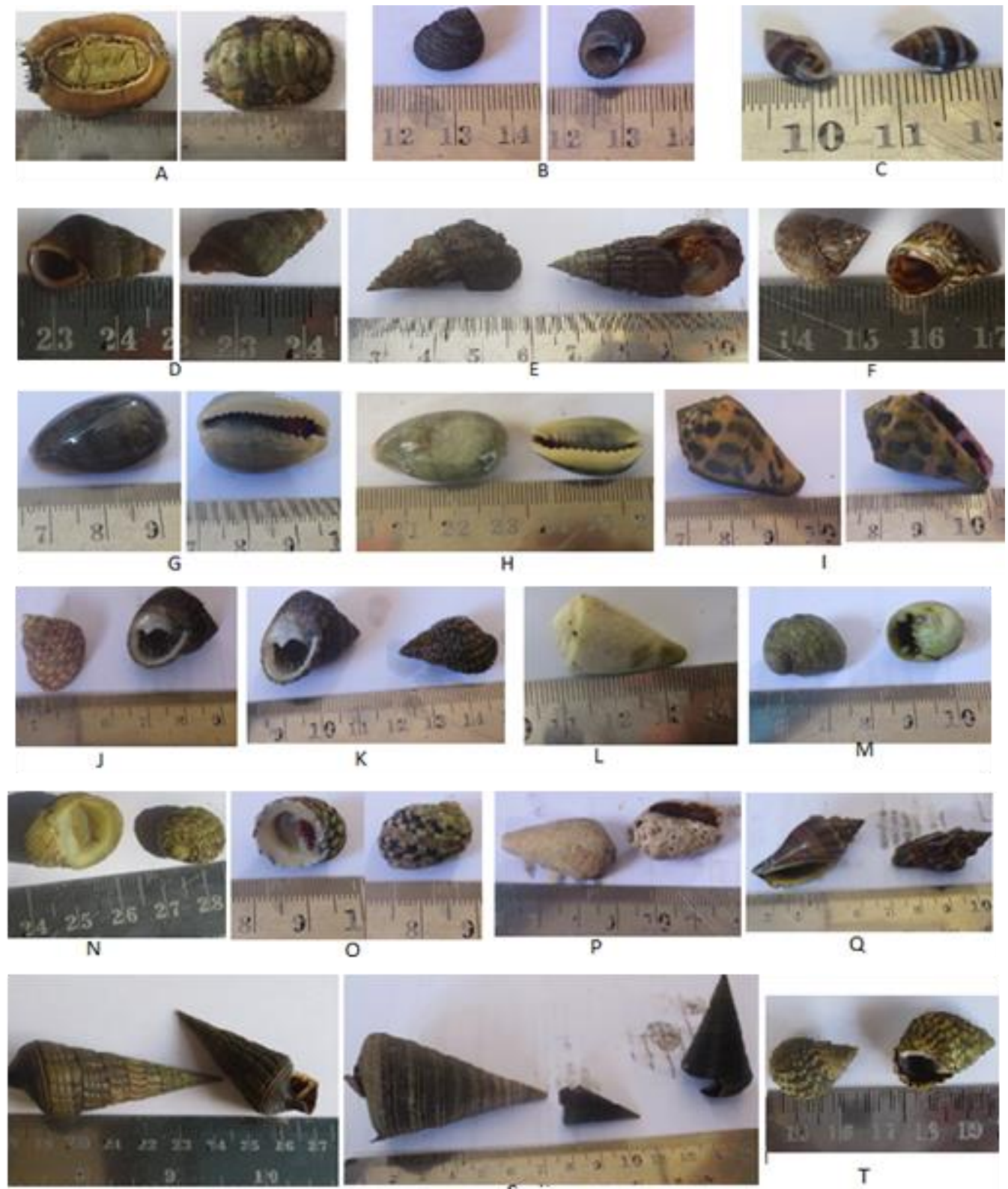

$\mathrm{R}$
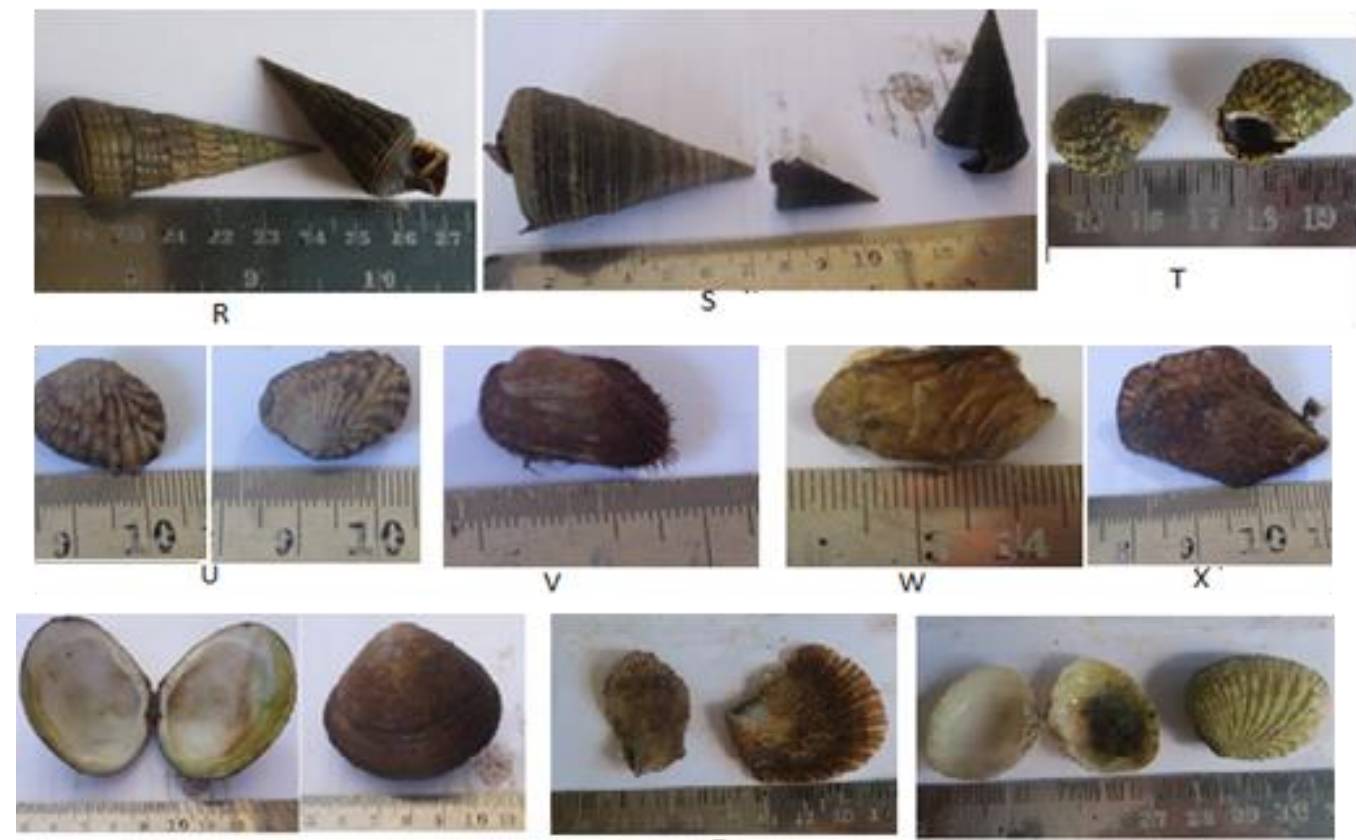

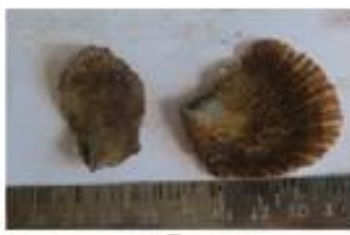

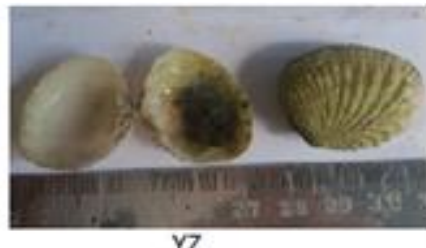

Figure 3. Species of mollusks in the mangroves of Pejarakan, Buleleng, Bali, Indonesia. A. Acanthopleura granulata; B. Assiminaea sp.; C. Cassidula sp.; D. Cerithidea obtusa; E. Cerithideopsilla alata; F. Littoraria strigata; G. Cypraea caputserpentis; H. Cypraea annulus; I. Conus sponsalis; J. Monodonta canalifera; K. Monodonta sp.; L. Conus frigidus; M. Nerita costata; N. Nerita sp.; O. Nerita planospira; P. Melampus sp.; Q. Semiricinula tissoti; R. Terebralia palustris; S. Telescopium telescopium; T. Planaxis sulcatus; U. Anadara sp.; V. Modiolus micropterus; W. Crassostrea rhizophorae; X. Saccostrea sp.; Y. Polymesoda bengalensis; Z. Ostrea edulis; YZ. Anadara granosa 
Species of Terebralia palustris was distributed in several plots in all mangrove zones. This indicates that this species has a great tolerance in wide range of mangrove habitat. Fratini et al. (2004); Patria and Putri (2017); Samsi et al. (2019) stated that $T$. palustris has a wide distribution and the ability to live in a variety of salinity, $\mathrm{pH}$, organic matter, and substrate types. Furthermore, it is also stated that $T$. palustris plays a major role in food webs, mangrove litter degradation and nutrient cycling in mangrove ecosystems.

Mollusk species from the Bivalvia class were distributed in the seaward zone and the middle zone. Bivalvia lives in muddy or sandy substrates. Habitat characteristics for Bivalvia are in accordance with the habitat type in the seaward zones (Table 2). It can be concluded that the high sludge substrate type can increase the abundance of Bivalvia because the sludge substrate type is very preferred by these organisms. Samir et al. (2017) stated that differences in the texture of the substrate can cause different species of mollusks that live on the substrate. The high abundance of Bivalvia is related to the high organic matter content of the substrate and the species of substrate containing sludge. Pakaya et al. (2017) also stated that Bivalvia is common biota that occupies mangrove habitat types with muddy substrates.

Species of blood clams (Anadara granosa and Anadara sp.) were distributed in the front and middle zones of the mangrove area. This habitat is characterized by the muddy, sandy habitat types with high tides (Table 2). Ginting et al. (2017) stated that blood clams are benthic animals that generally inhabit tidal areas (intertidal zones). These shells usually occupy the upper part of the zone which is the area of the average high tide and the middle area between high and low tides. A. granosa is often referred to as blood clam because of the red-brown color of the flesh.

There was only one species from the Chiton group found, namely Acanthopleura granulate. This species was only found in the seaward zone and was distributed in groups in two sample plots, associated with coral, and attached to rock. All chitons live in marine waters, occupying the littoral zone, especially the intertidal area. Members of the Chitonidae family of the Polyplacophora class live attached, sometimes tightly attached, to rock surfaces with the help of dorsoventral muscles or crawling on the surface of coral reefs.

The clustering pattern of mollusks is related to the availability of resources that are not uniform across habitats, but resembles clustered pattern. The distribution in groups indicates that particular mollusk species are only suitable for a particular habitat. Pribadi et al. (2009) also found that the distribution pattern of mollusks, especially gastropods in the mangrove area of Segara Anakan Cilacap, Central Java, Indonesia generally has a clustered distribution pattern. In nature, the distribution of the population of organisms generally has a clustered distribution pattern and is very rarely found in a uniform pattern (i.e. evenly distributed). The cause of a species to live in groups is due to the nature of the species to form group in habitats that contain lots of food. Apart from dietary factors, physical and chemical factors, and the state of the substrate also play a role in influencing the distribution pattern of mollusks.

In conclusion, there were 27 species of mollusks, consisting of 19 species of Gastropoda, 7 species of Bivalvia, and 1 species of Polyplacophora. The mangrove zone in the seaward zone showed the highest diversity of mollusks species and the lowest was in the landward zone. T. palustris had the highest abundance and were distributed in the three mangrove zones. Planaxis sulcatus had the highest abundance in the seaward zone and Telescopium telescopium showed a fairly high abundance and was distributed in the middle zone and the landward zone. In general, the distribution of mollusks in the coastal mangrove area of Pejarakan Buleleng is in a clustered pattern.

\section{ACKNOWLEDGMENTS}

We would like to thank the Heads of the Faculty of Mathematics and Natural Sciences and the Institute for Research and Community Service at Udayana University for funding this research. Thanks to Mr. Gatot for facilitating the data collection in the field. We thank Gede Yeyen Suharta and Made Oka Wedyanta for assisting with research in the field.

\section{REFERENCES}

BMKG region III Bali. 2019. Bali Region Monthly Rain. Agency for Meteorology, Climatology and Geophysics Region III, Denpasar. http://balai3.denpasar.bmkg.go.id

Baderan DWK, Hamidun MS, Utina RI, Rahim S, Dali R. 2019. The abundance and diversity of Mollusks in mangrove ecosystem at coastal area of North Sulawesi, Indonesia. Biodiversitas 20 (4): 987993. DOI: 10.13057/biodiv/d200408

Fratini S, Vigiani V, Vannini M, Cannicci S. 2004. Terebralia palustris (Gastropoda; Potamididae) in a Kenyan mangal: Size structure, distribution and impact on the consumption of leaf litter. Mar Biol 144 (6): 1173-1182.

Giesen, W., Wulffraat, S., Zieren, M. and Scholten, L. 2007. Mangrove Guidebook for Southeast Asia. FAO, Rome and Wetlands International, Dharmasarn Co., Ltd

Ginantra IK, Suaskara IBM, Joni M. 2018. Diversity of mangrove plant for support ecotourism activities in Nature Conservation Forum Putri Menjangan, Pejarakan Buleleng-Bali. J Environ Manag Tour 5 (29): 987-994.

Ginting EDD, Susetya IG, Patana P, Desrita. 2017. Identification of Bivalvia in Tanjungbalai Waters, North Sumatera Province. Acta Aquatica 4 (1): 13-20. DOI: 10.29103/aa.v4i1.318.

Halim SSA, Shuib S, Talib A, Yahya K. 2019. Species composition, richness, and distribution of mollusks from intertidal areas at Penang Island, Malaysia. Songklanakarin J Sci Technol 41 (1): 165-173.

Hotchkiss ER, Hall JRO. 2010. Linking calcification by exotic snails to stream inorganic carbon cycling. Oecologia 163: 235-244. DOI: 10.1007/s00442-009-1536-1.

Kabir M, Abolfathi M, Hajimoradloo A, Zahedi S. 2014. Effect of mangroves on distribution, diversity and abundance of mollusks in mangrove ecosystem: A review. AACL Bioflux 7 (4): 286-300.

Ministry of Environment and Forestry. 2017. Own 23\% of the World Mangrove Ecosystem, Indonesia Master of the 2017 Mangrove International http://ppid.menlhk.go.id/siaran_pers/browse/561. 
Mujiono N. 2016. Mangrove Gastropods from Lombok Island, West Nusa Tenggara. Oseanologi dan Limnologi di Indonesia 1 (3): 39-50. DOI: 10.14203/oldi.2016.v1i3.55. [Indonesia]

NCF Putri Menjangan. 2016. Profil of NCF Putri Menjangan Bali. [Report]. Pejarakan Village, Indonesia.

Nursalwa B, Marshall DJ. 2014. Common Aquatic Gastropods of Brunei Institute for Biodiversity and Environmental Research Universit Brunei Darussalam, Brunei Darussalam.

Pechenik, I.A. 2000. Biology of the Invertebrates. McGraw-Hill Education \& University of California, San Fransisco.

Pakaya F, Olii AH, Panigoro C. 2017. Diversity and abundance of bivalves in the mangrove ecosystem in Mananggu Village, Mananggu District, Boalemo Regency. Jurnal Ilmiah Perikanan dan Kelautan 5 (1): 31-34.

Patria MP, Putri SA. 2017. The role of Terebralia (Gastropoda: Potamididae) in carbon deposits at mangrove forest Pulau Panjang, Serang Banten. AIP Conf Proc 1844 (1): 040002. DOI: 10.1063/1.4983438.

Piranto D, Riyantini I, Kurnia MUA, Prihadi DJ. 2019. Sediment characteristics and effect on abundance gastropoda in the mangrove ecosystem in Pramuka Island. Jurnal Perikanan dan Kelautan 10 (1): $20-28$
Pribadi R, Hartati R, Chrisna. 2009. Composition of species and distribution of gastropods in the mangrove forest of Segara Anakan Cilacap. Jurnal Ilmu Kelautan 14 (2): 102-111.

Putra S, Ali M, Huda I. 2018. The distribution pattern of gastropods in the mangrove ecosystem of the Reuleung Leupung River, Aceh Besar District. Jurnal Biotik 6 (1): 59-62.

Sahidin A, Wardiatno Y, Setyobudiandi I. 2019. Biodiversity and spatial distribution of mollusks in Tangerang coastal waters, Indonesia. AACL Bioflux 12 (6): 2051-2061.

Samir, Nurgayah W, Ketjulan R. 2017. Study on density and distribution pattern of bivalvia in mangrove area of Balimu of South Lasalimu, Buton. Jurnal Manajemen Sumber Daya Perairan 1 (2): 169-181.

Samsi AN, Omar SBA, Niartiningsih A, Soekendarsi E. 2019. Morphometric variations of Terebralia palustris Linnaeus 1967 in mangrove ecosystems. Intl J Sci Technol Res 8 (10): 3787-3789.

Stiling P. 1996. Ecology, Theories, and Applications. Prentice Hall International Inc, New Jersey.

Tan SK, Clements R. 2008. Taxonomy and distribution of the Neritidae (Mollusca: Gastropoda) in Singapore. Zool Stud 47 (4): 481-494.

Widiana R, Nurdin J, Amelia N. 2016. Density and distribution pattern of Polymesoda bengalensis Lamarck in Muaro Nipah Waters, South Coastal District, West Sumatra. Prosiding Seminar Nasional from Basic Science to Comprehensive Education. Makassar, 26 Agustus 2016. 